\title{
PENGARUH EFEKTIVITAS KEPEMIMPINAN DAN LINGKUNGAN KERJA TERHADAP KINERJA KARYAWAN \\ DENGAN PERAN MEDIASI KEPUASAN KERJA (Studi pada PD. BPR BKK Batang)
}

\author{
Rasmuji \\ Fakultas Ekonomika dan Bisnis UNTAG Semarang \\ Email: rasmuji.perekonomian@gmail.com \\ H. Ratnawati Dwi Putranti \\ Fakultas Ekonomika dan Bisnis UNTAG Semarang \\ Email: ratna.permai@gmail.com
}

\begin{abstract}
Abstrak
Penelitian ini bertujuan untuk menganalisis pengaruh efektivitas kepemimpinan dan lingkungan kerja terhadap kepuasan kerja dan kinerja karyawan PD. BPR BKK Batang. Populasi penelitian adalah karyawan PD. BPR BKK Batang sejumlah 91 orang. Teknik pengambilan sampel dalam penelitian ini digunakan purposive sampling, dengan kriteria bukan berpendidikan SD dan SMP, dan bukan pimpinan, didapatkan 77 orang sebagai sampel. Analisis data menggunakan analisis jalur dengan alat bantu SPSS versi 19. Hasil penelitian menunjukkan bahwa efektivitas kepemimpinan dan lingkungan kerja berpengaruh positif dan signifikan terhadap kepuasan kerja karyawan. Efektivitas kepemimpinan, lingkungan kerja dan kepuasan kerja berpengaruh positif dan signifikan terhadap kepuasan kerja karyawan. Variabel kepuasan kerja merupakan variabel yang memediasi pengaruh efektivitas kepemimpinan dan lingkungan kerja terhadap kinerja karyawan.
\end{abstract}

Kata kunci: Efektivitas kepemimpinan, lingkungan kerja, kepuasan kerja dan kinerja karyawan.

\section{Abstract}

This study aims to analyze the influence of leadership effectiveness and work environment on job satisfaction and employee performance PD. BPR BKK Batang. The study population is employees of PD. BPR BKK Batang a total of 91 peoples. Sampling technique in this study used purposive sampling, with the criteria not educated elementary and junior high, and not the leader, obtained 77 people as a sample. Data analysis using path analysis with SPSS tool version 19. The results showed that the effectiveness of leadership and work environment have a positive and significant impact on employee job satisfaction. The effectiveness of leadership, work environment and job satisfaction have a positive and significant effect on employee job satisfaction. Job satisfaction variable is a variable that mediates the influence of leadership effectiveness and work environment on employee performance.

Keywords: leadership effectiveness, work environment, job satisfaction and employee performance 


\section{PENDAHULUAN}

Kepemimpinan sangat penting dalam setiap organisasi, pemimpin yang baik akan menyebabkan kelancaran fungsi, karyawan termotivasi dan secara ke seluruhan efektivitas dalam kinerja organisasi (Bus, Review, John, \& Chattopadhyay, 2015). Efektivitas kepemimpinan ditunjuk dari profesionalisme seorang pemimpin yang sesuai dengan posisi dan eksistensi organisasinya, dimana pemimpin dituntut untuk menguasai berbagai apek manajerial yang berkaitan dengan perilaku organisasinya, karena dengan memahami aspek manajerial tersebut dapat digunakan untuk menopang tugas utama pemimpin baik dalam berpikir secara konsepsional, membina kreativitas, mewujudkan kondisi organisasi yang harmonis, maupun ketika dirinya mengitegrasikan antara aspek struktur, proses, teknologi dan manusia (Sujak, 2009). Efektivitas kepemimpinan merupakan salah satu faktor yang mempengaruhi kepuasan kerja dan kinerja karyawan. Banyak penelitian yang telah menganalisis pengaruh efektivitas kepemimpinan terhadap kinerja karyawan. Penelitian yang dilakukan oleh Triayong, dkk (2013) menyatakan bahwa efektivitas kepemimpinan memiliki pengaruh terhadap kinerja pegawai. Selanjutnya penelitian yang dilakukan oleh Fanggidae (2015), membuktikan bahwa efektivitas kepemimpinan berpengaruh terhadap kinerja karyawan.

Kinerja merupakan suatu fungsi dari motivasi dan kemampuan. Untuk menyelesaikan tugas atau pekerjaan seseorang sepatutnya memiliki derajat kesediaan dan tingkat kemampuan tertentu. Kesediaan dan ketrampilan seseorang tidaklah cukup efektif untuk mengerjakan sesuatu tanpa pemahaman yang jelas tentang apa yang dikerjakan dan bagaimana mengerjakannya (Rivai, 2011).

Heriyanti (2007) menyatakan bahwa kinerja sumber daya manusia akan terpenuhi apabila kepuasan kerja sebagai unsur yang berpengaruh terhadap kinerja dapat tercipta dengan sempurna. Penelitian mengenai kepuasan kerja telah banyak dilakukan oleh para peneliti. Yahya (2011) menganalisis pengaruh peran kepemimpinan dan motivasi terhadap kepuasan kerja dan pengaruhnya terhadap kinerja karyawan. Penelitian lain dilakukan oleh Tjandra, Setiawati (2013), yang membuktikan bahwa kepuasan kerja dipengaruhi oleh lingkungan kerja, kepemimpinan dan motivasi kerja.

Faktor lain yang mempengaruhi kepuasan kerja dan kinerja karyawan adalah lingkungan kerja. Umar (2010) mengungkapkan lingkungan kerja yang baik dapat mendukung pelaksanaan kerja sehingga karyawan memiliki semangat bekerja dan meningkatkan kinerja karyawan. Penelitian mengenai lingkungan kerja telah dilakukan oleh beberapa peneliti, diantaranya dilakukan oleh Riandani (2012) menyimpulkan bahwa lingkungan kerja mempengaruhi kinerja karyawan. Begitu juga penelitian yang dilakukan oleh Shalahuddin (2013) menjelaskan lingkungan kerja berpengaruh terhadap kinerja karyawan.

Selain efektivitas kepemimpinan yang mempengaruhi kepuasan kerja dan kinerja karyawan adalah faktor lingkungan kerja. Lingkungan kerja merupakan segala sesuatu yang ada di sekitar pekerja dan dapat mempengaruhi dalam bekerja meliputi pengaturan penerangan, pengontrolan suara gaduh, pengaturan kebersihan tempat kerja dan pengaturan keamanan tempat kerja (Sukanto dan Indriyo, 2010). Penelitian mengenai lingkungan kerja telah dilakukan oleh beberapa peneliti, diantaranya dilakukan oleh Riandani (2012) bahwa lingkungan kerja mempengaruhi kinerja karyawan. Begitu juga penelitian yang dilakukan oleh Shalahuddin (2013) menjelaskan lingkungan kerja berpengaruh terhadap kinerja karyawan.

Obyek dari penelitian ini adalah PD. BPR BKK Batang merupakan Badan Pengkreditan Rakyat dengan jumlah sebanyak 91 karyawan dari staf 
manajemen hingga petugas kebersihan dan satpam.

Upaya yang dilakukan pimpinan dalam pencapaian target perusahaan masih mengalami beberapa kendala, diantaranya: tingginya target pendapatan kepada karyawan, kurangnya sarana prasarana pendukung lngkungan kerja, kurangnya reward kepada karyawan, komunikasi yang kurang baik antara pimpinan atau manajemen dengan karyawan pada PD. BPR BKK Batang.

Selain kesenjangan (fenomena gap) yang terjadi, dalam penelitian-penelitian sebelumnya masih terdapat perbedaan hasil penelitian antara hubungan efektifitas kepemimpinan dan lingkungan kerja terhadap kinerja karyawan. Efektivitas kepemimpinan dapat mempengaruhi kinerja karyawan, penelitian yang dilakukan oleh Triayong dkk (2013) dan Fanggidae (2015) menyatakan bahwa efektivitas kepemimpinan mempengaruhi kinerja karyawan. Sedangkan penelitian yang dilakukan oleh Prijanto, dkk (2011) menyatakan efektivitas kepemimpinan tidak berpengaruh terhadap kinerja karyawan.

Dermawan, et al (2012), Masrukin dan Waridin (2016), Yanti (2011), menemukan bahwa selain efektivitas kepemimpinan, lingkungan kerja mempengaruhi kinerja karyawan. Hal tersebut menunjukkan bahwa semakin baik lingkungan kerja akan mempengaruhi kinerja karyawan. Sedangkan penelitian Suhaji (2012), Tjandra dan Setiawati (2013) menemukan lingkungan kerja tidak berpengaruh signifikan terhadap kinerja karyawan.

Ditinjau dari hasil penelitian terdahulu tersebut pada hubungan efektivitas kepemimpinan dan lingkungan kerja dengan kinerja karyawan masih terdapat kontroversi hasil beberapa peneliti (research gap).

Berdasarkan latar belakang permasalahan, fenomena gap dan research gap tersebut, permasalahan penelitian yang diajukan adalah: Bagaimanakah Pengaruh
Efektivitas Kepemimpinan dan Lingkungan Kerja Terhadap Kinerja Karyawan dengan Variabel Mediasi Kepuasan Kerja (Studi pada PD. BPR BKK Batang).

PENGEMBANGAN MODEL PENELITIAN

\section{Efektivitas Kepemimpinan dengan Kepuasan Kerja Karyawan}

Seorang pemimpin memiliki yang efektivitas kepemimpinan yang efektif akan menentukan gaya kepemimpinan didasarkan pada perilaku atasan dalam berkomunikasi, hubungan dengan bawahan dan kemampuannya memecahkan masalah. Kepuasan kerja karyawan merupakan suatu perasaan yang menyokong atau tidak menyokong diri karyawan yang berhubungan dengan pekerjaannya maupun kondisi dirinya. Penilaian karyawan terhadap pekerjaan dengan kondisi dirinya erat hubungannya dengan kepuasan kerja karyawan. Hal ini disebabkan oleh penilaian yang positif dapat meningkatkan kepuasan kerja karyawan, sedangkan penilaian yang negatif dapat mengakibatkan ketidakpuasan kerja karyawan. Keefektifan pemimpin menciptakan kondisi kerja yang baik akan mempengaruhi kepuasan kerja karyawan. Penelitian sebelumnya yang dilakukan oleh Wicaksono (2013) menyatakan bahwa efektivitas kepemimpinan berpengaruh terhadap kepuasan kerja pehawai. Begitu juga dengan penelitian lainnya yang dilakukan oleh Yanti (2011), Tjandra dan Setiawati (2013), Septiana (2013) dan Trianka (2015) yang menyatakan kepemimpinan berpergaruh terhadap kepuasan kerja karyawan.

\section{H1 : Efektifitas Kepemimpinan ber- pengaruh positif dan signifikan terhadap Kepuasan Kerja}




\section{Lingkungan Kerja dengan Kepuasan Kerja Karyawan}

Lingkungan kerja yang memadai tentunya akan membuat karyawan betah bekerja, sehingga akan timbul semangat kerja dan kegairahan kerja karyawan dalam melakasanakan pekerjaannya, kinerja karyawan akan meningkat. Sedangkan lingkungan kerja yang tidak memadai dapat mengggangu konsentrasi karyawan dalam melaksanakan pekerjaaannya sehingga menimbulkan kesalahan dalam bekerja dan kinerja karyawan akan menurun.

Untuk mencapai kepuasan kerja diperlukan adanya peningkatan lingkungan kerja, yaitu penyediaan sarana dan prasarana yang mendukung pelaksanaan kerja yang baik. Penelitian sebelumnya yang dilakukan oleh Tjandra dan Setiawati (2013), Septiana (2013) dan Trianka (2015) membuktikan bahwa lingkungan kerja berpergaruh terhadap kepuasan kerja karyawan.

\section{H2 : Lingkungan Kerja berpengaruh positif dan signifikan terhadap Kepuasan Kerja}

\section{Hubungan Efektivitas Kepemimpinan dengan Kinerja Karyawan}

Seorang pemimpin bisa dikatakan efektif apabila mempunyai profesionalisme yang sesuai dengan posisi dan eksistensi organisasinya, maka pemimpin dituntut untuk menguasai berbagai apek manajerial yang berkaitan dengan perilaku organisasinya, karena dengan memahami aspek manajerial tersebut dapat digunakan untuk menopang tugas utama pemimpin baik dalam berpikir secara konsepsional, membina kreativitas, mewujudkan kondisi organisasi yang harmonis, maupun ketika dirinya mengitegrasikan antara aspek struktur, proses, teknologi dan manusia. Sehingga Efektivitas kepemimpinan sangat mempengaruhi kinerja karyawan. Penelitian sebelumnya yang dilakukan oleh Triayong dkk (2013) dan Fanggidae (2015) menyatakan bahwa efektivitas kepemim- pinan mempengaruhi kinerja karyawan. Sedangkan penelitian yang dilakukan oleh Prijanto, dkk (2011) menyatakan efektivitas kepemimpinan tidak berpengaruh terhadap kinerja karyawan.
H3 : Efektifitas kepemimpinan ber- pengaruh positif dan signifikan terhadap kinerja karyawan

\section{Lingkungan Kerja dengan Kinerja Karyawan}

Kondisi lingkungan dapat mempengaruhi kinerja karyawan seperti yang dikemukakan Robbins (2006), bahwa para karyawan menaruh perhatian yang besar terhadap lingkungan kerja mereka, baik dari segi kenyamanan pribadi maupun kemudahan melakukan pekerjaan dengan baik. Lingkungan kerja dapat dibedakan menjadi dua, yaitu lingkungan kerja fisik dan lingkungan kerja non fisik. Terciptanya lingkungan kerja yang baik dapat berpengaruh terhadap kinerja karyawan. Lingkungan kerja fisik dan lingkungan kerja non fisik juga berpengaruh terhadap motivasi dan semangat kerja karyawan karena apabila lingkungan kerja di perusahaan tersebut nyaman dan menyenangkan tentunya karyawan dapat meningkatkan kinerjanya sehingga tujuan perusahaan dapat tercapai dengan baik.

Penelitian sebelumnya yang dilakukan oleh Nugraha (2009), Rokhilah dan Darmanto (2014), Larasati (2016) membuktikan bahwa lingkungan kerja berpergaruh terhadap kinerja karyawan.

\section{H4 : Lingkungan kerja berpengaruh positif dan signifikan terhadap Kinerja Karyawan}

\section{Kepuasan Kerja dengan Kinerja Karyawan}

Kepuasan kerja adalah perasaan dan penilaian karyawan mengenai pekerjaannya dalam hubungannya dengan apakah pekerjaannya mampu memenuhi harapan, kebutuhan, dan keinginannya. 
Menurut Luthans (2009), pada dasarnya seseorang dalam bekerja akan merasa nyaman dan tinggi kesetiannya pada perusahaan apabila dalam bekerjanya memperoleh kepuasan kerja sesuai dengan apa yang diinginkan. Penelitian sebelumnya dilakukan Huda (2012) membuktikan bahwa kepuasan kerja memberikan pengaruh terhadap kinerja karyawan.
H5 : Kepuasan Kerja berpengaruh positif dan signifikan terhadap Kinerja Karyawan

Model kerangka pikir dapat dijelaskan pada Gambar 1.

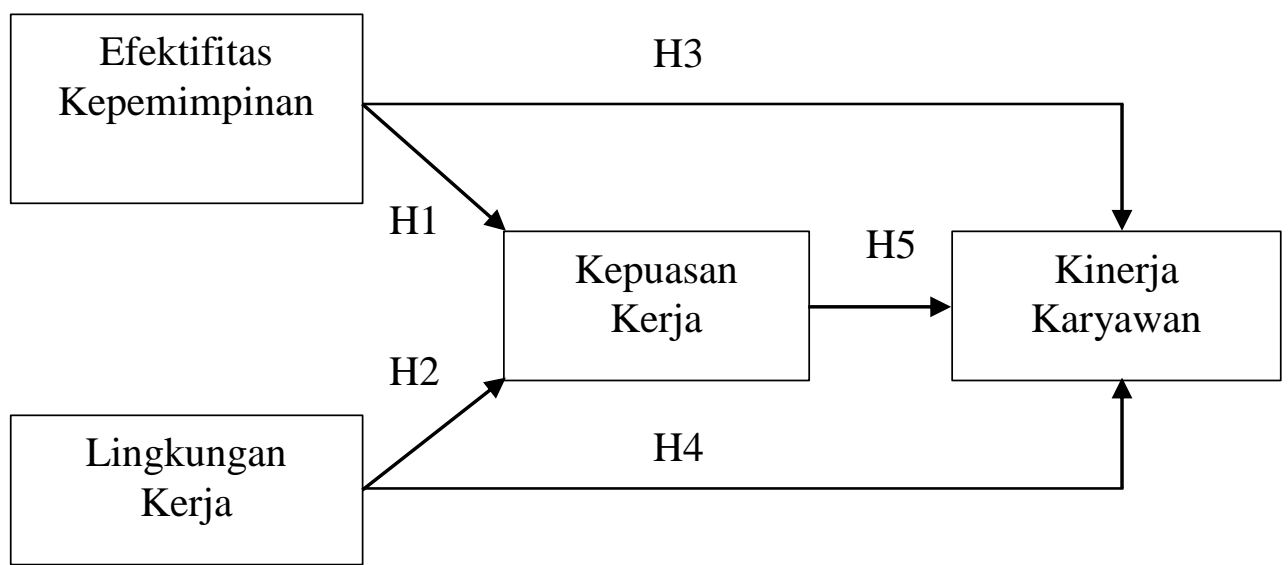

Sumber : Hasil Pengembangan untuk studi ini.

\section{Gambar 1. Kerangka Pemikiran}

\section{METODE PENELITIAN}

\section{Populasi dan Sampel}

Populasi adalah karyawan yang bekerja di PD BPR BKK Batang sebanyak 91 orang. Teknik pengambilan sampel dalam penelitian ini digunakan proportional sampling, yaitu cara pengambilan sampel dari populasi yang terdiri dari strata yang mempunyai susunan bertingkat (Sugiyono, 2009). Berdasarkan kriteria tersebut, maka jumlah sampel sebanyak 76 orang karyawan, karena 8 orang adalah pimpinan langsung yang menilai kinerja karyawan, dan 7 orang karyawan yang memiliki tingkat pendidikan rendah (SD dan SMP).

\section{Definisi Operasional Variabel}

Definisi operasional diperlukan agar suatu konsep yang abstrak bisa diukur. Adapun definisi operasional dari masingmasing variabel penelitian ini dapat di lihat pada Tabel 1.

\section{Analisis Data}

Penelitian ini digunakan model analisis jalur (path analysis) dengan menggunakan pendekatan model regresi linier berganda.

\section{HASIL DAN PEMBAHASAN Profil Responden}

Tingkat tanggapan responden (respons rate) adalah $100 \%$ yakni 77 karyawan. Deskripsi profil responden penelitian pada Tabel 1 dapat dijelaskan kebanyakan berjenis kelamin laki-laki, umur didominasi 31-40 tahun, pendidikan dominan sarjana, dan masa kerja paling banyak lebih dari 17 tahun.

\section{Deskripsi Variabel Penelitian}

Penilaian responden terhadap keempat variabel penelitian dilakukan dengan analisis deskriptif nilai indeks yang menunjukkan ukuran statistik, dapat dilihat pada Tabel 3. Hasil ini dapat dijelaskan dari keempat variabel penelitian, variabel efektivitas kepemimpinan menunjukkan 
nilai indeks tertinggi 73.41, diikuti lingkungan kerja 68,40, kepuasan kerja 67,34, dan kinerja karyawan 64,72.

\section{Pengujian Validitas dan Reliabilitas}

Alat uji yang digunakan untuk mengukur tingkat interkorelasi antar variabel dan dapat tidaknya dilakukan analisis faktor dimana instrumen dikatakan valid jika nilai KMO lebih besar 0,5 dan loading factor lebih besar 0,4 (Ghozali, 2011).

Berdasarkan hasil pada Tabel 4 dapat ditunjukkan bahwa seluruh item pertanyaan pada variabel penelitian memiliki nilai KMO lebih besar dari 0,05 dan nilai loading factor untuk setiap item-item pertanyaan lebih besar dari 0,40, sehingga layak digunakan sebagai indikator dari variabel penelitian.

Hasil uji reliabilitas pada Tabel 5 diketahui bahwa semua nilai Alpha adalah lebih besar dari 0,70, sehingga semua variabel dinyatakan reliabel. Dengan demikian jawaban responden terhadap indikator pernyataan dapat digunakan dalam penelitian ini.

\section{Uji Normalitas}

Uji Normalitas untuk lebih tepatnya dibantu dengan menggunakan Uji Kolmogorov-Smirnov. Hasil uji KS dapat pada Tabel 6 dapat diketahui bahwa nilai Asymp signifikansi (2-tailed) berada di atas level of significance 5\% (0,184 > 0,05), maka dapat dijelaskan bahwa data yang digunakan adalah berdistribusi normal.

\section{Uji Multikolinieritas}

Hasil uji multikolinieritas pada tabel 5 dapat diketahui bahwa nilai tolerance variabel independen lebih besar dari 0.10. Karena tidak variabel independen penelitian memiliki nilai tollerance kurang dari 0.10 yang berarti tidak ada korelasi antar variabel independen yang nilainya lebih dar 95\%. Jadi dapat disimpulkan bahwa tidak ada multikolinieritas antar variabel independen dalam model regresi.

\section{Uji Heterokedastisitas}

Hasil uji heterokedastisitas dengan uji Glejser disajikan pada Tabel 6 dapat diketahui bahwa nilai signifikansi berada di atas level of signifance 5\%, yaitu variabel efektivitas kepemimpinan sebesar 0,259 , variabel lingkungan kerja sebesar 0,618 dan variabel kepuasan kerja sebesar 0,135 sehingga dapat dikatakan variabel independen tidak terjadi heterokedastisitas.

\section{Analisis Regresi}

\section{Uji Mediasi I (Analisis Regresi I)}

Uji model mediasi ini untuk menguji pengaruh variabel efektivitas kepemimpinan $\left(\mathrm{X}_{1}\right)$ dan lingkungan kerja $\left(\mathrm{X}_{2}\right)$ terhadap Kepuasan kerja (Y). Hasil analisis mediasi dapat dilihat pada Tabel 9.

Berdasar Tabel 9 dapat dibentuk persamaan sebagai berikut.

Kepuasan Kerja $=$ 0,467Efektivitas Kepemimpinan + 0,233Lingkungan Kerja

Dari persamaan ini diketahui bahwa koefisien efektivitas kepemimpinan dan lingkungan kerja memiliki nilai positif artinya.

a. Efektivitas Kepemimpinan berpengaruh positif terhadap kepuasan kerja artinya semakin baik Efektivitas Kepemimpinan semakin tinggi kepuasan kerja karyawan PD. BPR BKK Batang.

b. Lingkungan kerja berpengaruh positif terhadap kepuasan kerja artinya semakin baik Lingkungan kerja semakin tinggi kepuasan kerja karyawan PD. BPR BKK Batang.

\section{Uji Mediasi II}

Uji model mediasi ini untuk menguji pengaruh Efektivitas Kepemimpinan $\left(\mathrm{X}_{1}\right)$, Lingkungan Kerja $\left(\mathrm{X}_{2}\right)$ dan Kepuasan Kerja (Y) terhadap Kinerja Karyawan (Z). Hasil analisis mediasi 2 dapat dilihat pada Tabel 10. 
Berdasar Tabel 10 dapat dibentuk persamaan sebagai berikut.

Kinerja Karyawan $=$ 0,234Efektivitas Kepemimpinan + 0,286Lingkungan Kerja $+0,354$ Kepuasan Kerja

Dari persamaan ini diketahui bahwa koefisien efektivitas kepemimpinan, lingkungan kerja dan kepuasan kerja terhadap kinerja karyawan memiliki nilai positif. Efektivitas kepemimpinan berpengaruh positif terhadap kinerja karyawan artinya semakin baik efektivitas kepemimpinan semakin tinggi kinerja karyawan PD. BPR BKK Batang. Lingkungan kerja berpengaruh positif terhadap kinerja karyawan artinya semakin baik lingkungan kerja semakin tinggi kinerja karyawan PD. BPR BKK Batang. Kepuasan kerja berpengaruh positif terhadap kinerja karyawan artinya semakin tinggi kepuasan kerja semakin tinggi kinerja karyawan PD. BPR BKK Batang.

\section{Uji Koefisien Determinasi}

Berdasarkan Tabel 9, dapat diketahui persentase kontribusi variabel efektivitas kepemimpinan dan lingkungan kerja sebesar 33,40\% dalam menjelaskan variabel dependen kepuasan kerja, sedangkan $66,60 \%$ dijelaskan variabel di luar model. Adapun persentase kontribusi variabel efektivitas kepemimpinan, lingkungan kerja dan kepuasan kerja sebesar 46,20\% dalam menjelaskan variabel dependen kinerja karyawan, sedangkan 53,80\% dijelaskan variabel di luar model.

\section{Uji F (Fit) Model}

Berdasar Tabel 10 dapat diketahui bahwa efektivitas kepemimpinan dan lingkungan kerja secara bersama-sama memengaruhi kepuasan kerja, karena uji ANOVA menunjukkan Ftest $=20,050$ dengan Sig. 0,000 adalah lebih kecil dari 0,05. Demikian pula efektivitas kepemimpinan, lingkungan kerja dan kepuasan kerja secara bersama-sama memengaruhi kinerja karyawan, karena hasil uji menunjukkan Ftest $=22,742$ dengan Sig. 0,000 adalah lebih kecil dari 0,05 . Sehingga model yang digunakan dalam penelitian ini adalah fit.

\section{Hasil Uji Hipotesis}

Pengujian hipotesis melalui uji $t$ yang dilakukan dengan membandingkan $\mathrm{t}$ hitung dengan $\mathrm{t}$ tabel pada taraf signifikan 0,05 (5\%), artinya apabila sig $<0,05$, hipotesis diterima dan apabila sig $>0,05$, hipotesis ditolak. Uji $t$ ini untuk membuktikan dan mengetahui pengaruh variabel bebas (independen) secara individual terhadap variabel terikat (dependen).

Efektivitas kepemimpinan memiliki nilai $\mathrm{t}$ hitung sebesar 4,645 dan nilai signifikansi $(\mathrm{sig})=0,000$ lebih kecil dari 0,05 artinya Efektivitas Kepemimpinan berpengaruh positif dan signifikan terhadap kepuasan kerja karyawan PD. BPR BKK Batang. Hasil penelitian ini sejalan dengan penelitian yang dilakukan oleh Wicaksono (2013) menyatakan bahwa efektivitas kepemimpinan berpengaruh terhadap kepuasan kerja pehawai. Begitu juga dengan penelitian lainnya yang dilakukan oleh Yanti (2011), Tjandra dan Setiawati (2013), Septiana (2013) dan Trianka (2015) yang menyatakan kepemimpinan berpergaruh terhadap kepuasan kerja karyawan.

Lingkungan kerja memiliki nilai $\mathrm{t}$ hitung sebesar 2,323 dan nilai signifikansi $($ sig $)=0,023$ lebih kecil dari 0,05 artinya lingkungan kerja berpengaruh positif dan signifikan terhadap kepuasan kerja karyawan PD. BPR BKK Batang. Hasil penelitian ini sejalan dengan penelitian yang dilakukan oleh Tjandra dan Setiawati (2013), Septiana (2013) dan Trianka (2015) membuktikan bahwa lingkungan kerja berpergaruh terhadap kepuasan kerja karyawan. 
Efektivitas kepemimpinan memiliki nilai $\mathrm{t}$ hitung sebesar 2,276 dan nilai signifikansi $(\mathrm{sig})=0,026$ lebih kecil dari 0,05 artinya efektivitas kepemimpinan berpengaruh positif dan signifikan terhadap Kinerja karyawan PD. BPR BKK Batang. Lingkungan kerja memiliki nilai $\mathrm{t}$ hitung sebesar 3,058 dan nilai signifikansi $($ sig) $=0,003$ lebih kecil dari 0,05 artinya lingkungan kerja berpengaruh positif dan signifikan terhadap Kinerja karyawan PD. BPR BKK Batang. Hasil penelitian ini sejalan dengan penelitian yang dilakukan oleh Nugraha (2009), Rokhilah dan Darmanto (2014), Larasati (2016) membuktikan bahwa lingkungan kerja berpergaruh terhadap kinerja karyawan.

Kepuasan kerja memiliki nilai $\mathrm{t}$ hitung sebesar 3,338 dan nilai signifikansi $(\mathrm{sig})=0,001$ lebih kecil dari 0,05 artinya kepuasan kerja berpengaruh positif dan signifikan terhadap Kinerja karyawan PD. BPR BKK Batang. Hasil penelitian ini sejalan dengan penelitian yang dilakukan oleh Huda (2012) membuktikan bahwa kepuasan kerja memberikan pengaruh terhadap kinerja karyawan.

\section{Analisis Jalur (Pengaruh Langsung dan Tidak Langsung)}

Pengaruh efektivitas kepemimpinan terhadap kinerja karyawan dengan mediasi kepuasan kerja, pengujian mediasi dalam penelitian ini dijelaskan pada Gambar 2.

Berdasarkan gambar 2 dapat dilakukan perhitungan, pengaruh efektivitas kepemimpinan ke kinerja karyawan adalah 0,234 , pengaruh tidak langsung efektivitas kepemimpinan ke kepuasan kerja ke kinerja karyawan adalah $0,467 \times 0,354=$ 0,165 , dan total pengaruh efektivitas kepemimpinan terhadap kinerja karyawan adalah $0,234+0,165=0,399$.

Dari perhitungan di atas menunjukkan hasil uji mediasi sebesar 0,165. Artinya nilai mediasi lebih kecil dari pengaruh langsung efektivitas kepemimpinan terhadap kinerja karyawan. Hal ini berarti Kepuasan kerja sebagai variabel yang memperlemah mediasi pengaruh efektivitas kepemimpinan terhadap kinerja karyawan PD. BPR BKK Batang.

Pengaruh lingkungan kerja terhadap kinerja karyawan dengan mediasi kepuasan kerja, pengujian mediasi dalam penelitian ini dijelaskan pada Gambar 3.

Berdasarkan gambar 3 dapat dilakukan perhitungan, pengaruh lingkungan kerja ke kinerja karyawan adalah 0,286, pengaruh tidak langsung lingkungan kerja ke kepuasan kerja ke kinerja karyawan adalah $0,233 \times 0,354=0,082$, dan total pengaruh lingkungan kerja terhadap kinerja karyawan adalah $0,286+0,082=$ 0,368 .

Berdasarkan perhitungan di atas menunjukkan hasil uji mediasi sebesar 0,082 . Artinya nilai intervening lebih kecil dari pengaruh langsung lingkungan kerja terhadap kinerja karyawan. Hal ini berarti kepuasan kerja sebagai variabel yang mengintervening tetapi memperlemah pengaruh efektivitas kepemimpinan terhadap kinerja karyawan PD. BPR BKK Batang.

\section{Uji Sobel (Sobel Test) \\ Pengaruh Efektivitas Kepemimpinan Terhadap Kinerja Karyawan dengan mediasi Kepuasan Kerja}

Untuk lebih mengetahui signifikansi pengaruh tidak langsung efektivitas kepemimpinan terhadap kinerja karyawan melalui kepuasan kerja, digunakan uji Sobel Test, Hasil perhitungan uji sobel adalah sebagai berikut: 


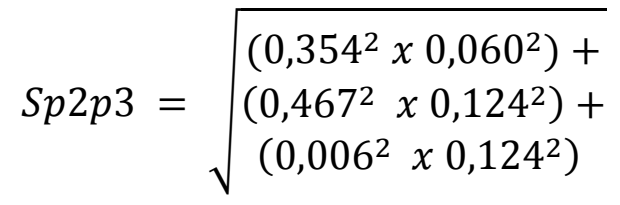

$S p 2 p 3=\sqrt{\begin{array}{c}0,000451+ \\ 0,003353+ \\ 0,000055\end{array}}$

$S p 2 p 3=\sqrt{0,00385983}$

$S p 2 p 3=0,062128$

Untuk menguji signifikansi pengaruh tidak langsung dari variabel independen terhadap variabel dependen, maka perlu menghitung nilai $t$ dari koefisien Sp2p3 dengan rumus sebagai berikut:

$$
\begin{aligned}
& t=\frac{0,467 \times 0,354}{0,062128} \\
& t=\frac{0,165318}{0,062128} \\
& =2,6609
\end{aligned}
$$

Berdasarkan hasil analisis diperoleh nilai $\mathrm{t}$ hitung $=2,6609$, jika dibandingkan dengan nilai t tabel sebesar 1,668, maka nilai $\mathrm{t}$ hitung lebih besar dari nilai $\mathrm{t}$ tabel $(2,6609>1,668)$. Dengan demikian menunjukan efektivitas kepemimpinan berpengaruh secara tidak langsung terhadap kinerja karyawan melalui kepuasan kerja, sehingga kepuasan kerja merupakan variabel yang memediasi.

\section{Pengaruh Lingkungan Kerja Terhadap Kinerja Karyawan dengan mediasi Kepuasan Kerja}

Untuk lebih mengetahui signifikansi pengaruh tidak langsung lingkungan kerja terhadap kinerja karyawan melalui kepuasan kerja, digunakan uji Sobel Test. Hasil perhitungan uji sobel adalah seperti berikut:

$$
S p 2 p 3=\sqrt{\begin{array}{ccc}
\left(0,354^{2}\right. & \times & \left.0,132^{2}\right)+ \\
\left(0,306^{2}\right. & x & \left.0,124^{2}\right)+ \\
\left(0,132^{2}\right. & x & \left.0,124^{2}\right)
\end{array}}
$$

$S p 2 p 3=\sqrt{\begin{array}{c}0,002184+ \\ 0,002308+ \\ 0,000268\end{array}}$

$S p 2 p 3=\sqrt{0,00239992}$

Sp2p3 = 0,048989

Untuk menguji signifikansi pengaruh tidak langsung dari variabel independen terhadap variabel dependen, maka perlu menghitung nilai $t$ dari koefisien $\mathrm{Sp} 2 \mathrm{p} 3$ dengan rumus sebagai berikut:

$$
\begin{aligned}
& t=\frac{0,306 \times 0,354}{0,048989} \\
& t=\frac{0,165318}{0,048989}=2,2111
\end{aligned}
$$

Berdasarkan hasil analisis diperoleh nilai $\mathrm{t}$ hitung $=2,2111$, jika dibandingkan dengan nilai t tabel sebesar 1,668, maka nilai t hitung lebih besar dari nilai t tabel $(2,2111>1,668)$. Dengan demikian menunjukan lingkungan kerja berpengaruh secara tidak langsung terhadap kinerja karyawan melalui kepuasan kerja, sehingga kepuasan kerja merupakan variabel yang memediasi. 


\section{Tabel 1. Definisi Operasional Variabel}

\begin{tabular}{|c|c|c|c|c|}
\hline No & Variabel & Definisi & Indikator & Skala \\
\hline 1 . & $\begin{array}{l}\text { Efektivitas } \\
\text { Kepemimpinan }\end{array}$ & $\begin{array}{l}\text { Efektivitas kepemimpinan adalah } \\
\text { seberapa jauh unit organisasi } \\
\text { pemimpin itu berhasil } \\
\text { melaksanakan tugas pencapaian } \\
\text { sasaran. (Yulk, 2010). (Robbins, } \\
\text { 2006) }\end{array}$ & $\begin{array}{l}\text { a. Hubungan pemimpin- } \\
\text { bawahan } \\
\text { b. Struktur tugas } \\
\text { c. Kekuatan posisi } \\
\text { kepemimpinan } \\
\text { (Robbins 2006) }\end{array}$ & $\begin{array}{l}\text { Skala } \\
\text { likert } \\
(1-7)\end{array}$ \\
\hline 2. & Lingkungan Kerja & $\begin{array}{l}\text { Lingkungan kerja adalah } \\
\text { lingkungan yang konkrit dan } \\
\text { abstrak yang meliputi dan } \\
\text { mengelilingi kerja seseorang } \\
\text { (Siagian 2008). }\end{array}$ & $\begin{array}{l}\text { a. Suasana kerja } \\
\text { b. Hubungan dengan rekan } \\
\text { sekerja } \\
\text { c. Tersedianya fasilitas } \\
\text { bekerja } \\
\text { (Nitisemito, 2012) }\end{array}$ & $\begin{array}{l}\text { Skala } \\
\text { likert } \\
(1-7)\end{array}$ \\
\hline 3. & Kepuasan Kerja & $\begin{array}{l}\text { Kepuasan kerja adalah suasana } \\
\text { psikologis tentang perasaan } \\
\text { menyenangkan atau tidak } \\
\text { menyenangkan } \\
\text { pekerjaan mereka (Rivai } 2011)\end{array}$ & $\begin{array}{l}\text { a. Pekerjaan itu sendiri } \\
\text { b. Pembayaran } \\
\text { c. Promosi } \\
\text { d. Kepenyeliaan } \\
\text { (supervisi) } \\
\text { e. Rekan kerja } \\
\text { (Luthans, 2009) }\end{array}$ & $\begin{array}{l}\text { Skala } \\
\text { likert } \\
(1-7)\end{array}$ \\
\hline 4. & $\begin{array}{l}\text { Kinerja } \\
\text { Karyawan }\end{array}$ & $\begin{array}{lrr}\text { Kinerja karyawan adalah hasil } \\
\text { kerja secara kualitas } & \text { dan } \\
\text { kuantitas yang dicapai oleh } \\
\text { seseorang karyawan dalam } \\
\text { melaksanakan tugasnya sesuai } \\
\text { dengan tanggungjawab yang } \\
\text { diberikan kepadanya } \\
\text { (Mangkunegara, 2009). }\end{array}$ & $\begin{array}{l}\text { a. Kualitas kerja } \\
\text { b. Kuantitas } \\
\text { c. Waktu produksi } \\
\text { d. Efektivitas kerja } \\
\text { e. Kemandirian } \\
\text { f. Komitmen kerja } \\
\text { (Robbins, 2006) }\end{array}$ & $\begin{array}{l}\text { Skala } \\
\text { likert } \\
(1-7)\end{array}$ \\
\hline
\end{tabular}

Tabel 2. Profil Responden

\begin{tabular}{lrr}
\hline \multicolumn{1}{c}{ Profil } & Frekuensi & Persen (\%) \\
\hline Jenis Kelamin & & \\
Laki-laki & 42 & 54,55 \\
Perempuan & 35 & 45,45 \\
\hline Umur & & \\
20-30 tahun & 42 & 54,55 \\
31-40 tahun & 35 & 45,45 \\
41 - 50 Tahun & 30 & 38,96 \\
$>$ 50 Tahun & 9 & 11,69 \\
\hline Pendidikan & & \\
SMA & 35 & 45,45 \\
Akademi / D3 & 2 & 2,60 \\
Sarjana (S1/S2) & 40 & 51,95 \\
\hline Masa Kerja & & \\
0-8 Tahun & 6 & 7,79 \\
9-17 Tahun & 32 & 41,56 \\
$>$ 17 Tahun & 39 & 50,65 \\
\hline
\end{tabular}


Tabel 3. Deskripsi Variabel Penelitian

\begin{tabular}{lll}
\hline Variabel dan Indikator & Nilai Indeks \\
\hline Efektivitas Kepemimpinan & 73,41 & \\
Hubungan pemimpin-bawahan & & 78,11 \\
Struktur tugas & & 71,80 \\
Kekuatan posisi kepemimpinan & & 70,31 \\
\hline Lingkungan Kerja & 68,40 & \\
Suasana kerja & & 67,53 \\
Hubungan dengan rekan sekerja & & 69,02 \\
Tersedianya fasilitas bekerja & 68,64 \\
\hline Kepuasan Kerja & 67,34 & \\
Pekerjaan itu sendiri & & 64,01 \\
Pembayaran & & 68,64 \\
Promosi & 67,90 \\
Kepenyeliaan & 68,28 \\
Rekan kerja & 69,39 \\
\hline Kinerja & 64,72 & \\
Kualitas kerja & & 68,46 \\
Kuantitas & 69,78 \\
Waktu produksi & 68,83 \\
Efektivitas kerja & 55,84 \\
Kemandirian & 59,00 \\
Komitmen kerja & 66,42 \\
\hline & &
\end{tabular}

Tabel 4. Hasil Uji Validitas

\begin{tabular}{lcc}
\hline \multicolumn{1}{c}{ Variabel } & Nilai KMO & Loading Factor \\
\hline Efektivitas Kepemimpinan & 0,741 & $0,410-0,799$ \\
Lingkungan Kerja & 0,752 & $0,435-0,824$ \\
Kepuasan kerja & 0,823 & $0,525-0,764$ \\
Kinerja Karyawan & 0,777 & $0,487-0,755$ \\
\hline
\end{tabular}

Tabel 5. Hasil Uji Reliabilitas

\begin{tabular}{lccc}
\hline \multicolumn{1}{c}{ Variabel } & Alpha Cronbach's & Kriteria Umum & Keterangan \\
\hline Efektivitas Kepemimpinan & 0,859 & 0,70 & Reliabel \\
Lingkungan Kerja & 0,772 & 0,70 & Reliabel \\
Kepuasan kerja & 0,848 & 0,70 & Reliabel \\
Kinerja karyawan & 0,821 & 0,70 & Reliabel \\
\hline
\end{tabular}


Tabel 6. Uji Kolmogorov-Smirnov

\begin{tabular}{llr}
\hline & & Unstandardized Residual \\
\hline $\mathrm{N}$ & & 77 \\
\hline Normal Parameters & &, $0 \mathrm{E}-7$ \\
& Mean & Std. Deviation \\
Most Extreme & Absolute &, 124 \\
Differences & Positive &, 059 \\
& Negative &,- 124 \\
\hline Test Statistic & & 1,092 \\
\hline Asymp. Sig. (2-tailed) & &, 184 \\
\hline
\end{tabular}

a. Test distribution is Normal.

b. Calculated from data.

Tabel 7. Hasil Uji Multikolinieritas

\begin{tabular}{llll}
\hline \multirow{2}{*}{ Model } & & \multicolumn{2}{c}{ Collinearity Statistics } \\
\cline { 3 - 4 } & & Tolerance & VIF \\
\cline { 2 - 4 } & (Constant) & & \\
\cline { 2 - 4 } & Efektivitas_Kepemimpinan & .672 & 1.489 \\
\cline { 2 - 4 } & Lingkungan_Kerja & .809 & 1.236 \\
\cline { 2 - 4 } & Kepuasan_Kerja & .649 & 1.541 \\
\hline
\end{tabular}

a. Dependent Variable: Kinerja_Karyawan

$\mathrm{s}$

Tabel 8. Hasil Uji Heterokedastisitas

\begin{tabular}{|c|c|c|c|c|c|c|}
\hline \multicolumn{7}{|c|}{ Coefficients $^{\mathbf{a}}$} \\
\hline & & $\begin{array}{r}\text { Unstand } \\
\text { Coeffi }\end{array}$ & $\begin{array}{l}\text { Irdized } \\
\text { ients }\end{array}$ & $\begin{array}{l}\text { Standardized } \\
\text { Coefficients }\end{array}$ & & \\
\hline \multicolumn{2}{|c|}{ Model } & $\mathrm{B}$ & Std. Error & Beta & $\mathrm{t}$ & Sig. \\
\hline \multirow[t]{4}{*}{1} & (Constant) & 4.715 & 3.686 & & 1.279 & .205 \\
\hline & $\begin{array}{l}\text { Efektivitas } \\
\text { Kepemimpinan }\end{array}$ & .053 & .046 & .157 & 1.137 & .259 \\
\hline & Lingkungan_Kerja & .046 & .092 & .063 & .502 & .618 \\
\hline & Kepuasan_Kerja & -.169 & .110 & -.303 & -1.154 & .135 \\
\hline
\end{tabular}

a. Dependent Variable: AbsUt 


\section{Tabel 9. Hasil Uji Mediasi I}

\begin{tabular}{lcccc}
\hline \multicolumn{1}{c}{ Hubungan Variabel } & Beta & t & Sig. & Keterangan \\
\hline Efektivitas Kepemimpinan terhadap Kepuasan Kerja & 0,467 & 4,645 & 0,000 & Signifikan \\
\hline Lingkungan Kerja terhadap Kepuasan Kerja & 0,233 & 2,323 & 0,023 & Signifikan \\
\hline
\end{tabular}

\section{Tabel 10. Hasil Uji Mediasi II}

\begin{tabular}{|c|c|c|c|c|}
\hline Hubungan Variabel & Beta & $\mathbf{t}$ & Sig. & Keterangan \\
\hline $\begin{array}{llll}\text { Efektivitas } & \text { Kepemimpinan } & \text { terhadap } & \text { Kinerja } \\
\text { Karyawan } & & \\
\end{array}$ & 0,234 & 2,726 & 0,026 & Signifikan \\
\hline Lingkungan Kerja terhadap Kinerja Karyawan & 0,286 & 3,058 & 0,003 & Signifikan \\
\hline Kepuasan Kerja terhadap Kinerja Karyawan & 0,354 & 3,338 & 0,001 & Signifikan \\
\hline
\end{tabular}

Tabel 11. Koefisien Determinasi

\begin{tabular}{lcc}
\hline \multicolumn{1}{c}{ Hubungan Variabel } & Adjusted R Square & $\begin{array}{c}\text { Std. Error of } \\
\text { the Estimate }\end{array}$ \\
\hline $\begin{array}{l}\text { Efektivitas Kepemimpinan }\left(\mathrm{X}_{1}\right) \text { dan } \\
\text { Lingkungan Kerja }\left(\mathrm{X}_{2}\right) \text { terhadap Kepuasan } \\
\text { Kerja }(\mathrm{Y})\end{array}$ & 0,334 & 4,101 \\
\hline $\begin{array}{l}\text { Efektivitas Kepemimpinan }\left(\mathrm{X}_{1}\right), \text { Lingkungan } \\
\text { Kerja }\left(\mathrm{X}_{2}\right) \text { dan Kepuasan Kerja }(\mathrm{Y}) \text { terhadap } \\
\text { Kinerja Karyawan }(\mathrm{Z})\end{array}$ & 0,462 & 4,391 \\
\hline
\end{tabular}

\section{Tabel 12. Hasil Uji F (ANOVA)}

\begin{tabular}{lcc}
\hline \multicolumn{1}{c}{ Hubungan variabel } & F-test & Sig. \\
\hline $\begin{array}{l}\text { Efektivitas Kepemimpinan }\left(\mathrm{X}_{1}\right) \text { dan Lingkungan Kerja }\left(\mathrm{X}_{2}\right) \\
\text { terhadap Kepuasan Kerja }(\mathrm{Y})\end{array}$ & 20,050 & 0,000 \\
\hline $\begin{array}{l}\text { Efektivitas Kepemimpinan }\left(\mathrm{X}_{1}\right) \text {, Lingkungan Kerja }\left(\mathrm{X}_{2}\right) \text { dan } \\
\text { Kepuasan Kerja }(\mathrm{Y}) \text { terhadap Kinerja karyawan }(\mathrm{Z})\end{array}$ & 22,742 & 0,000 \\
\hline
\end{tabular}




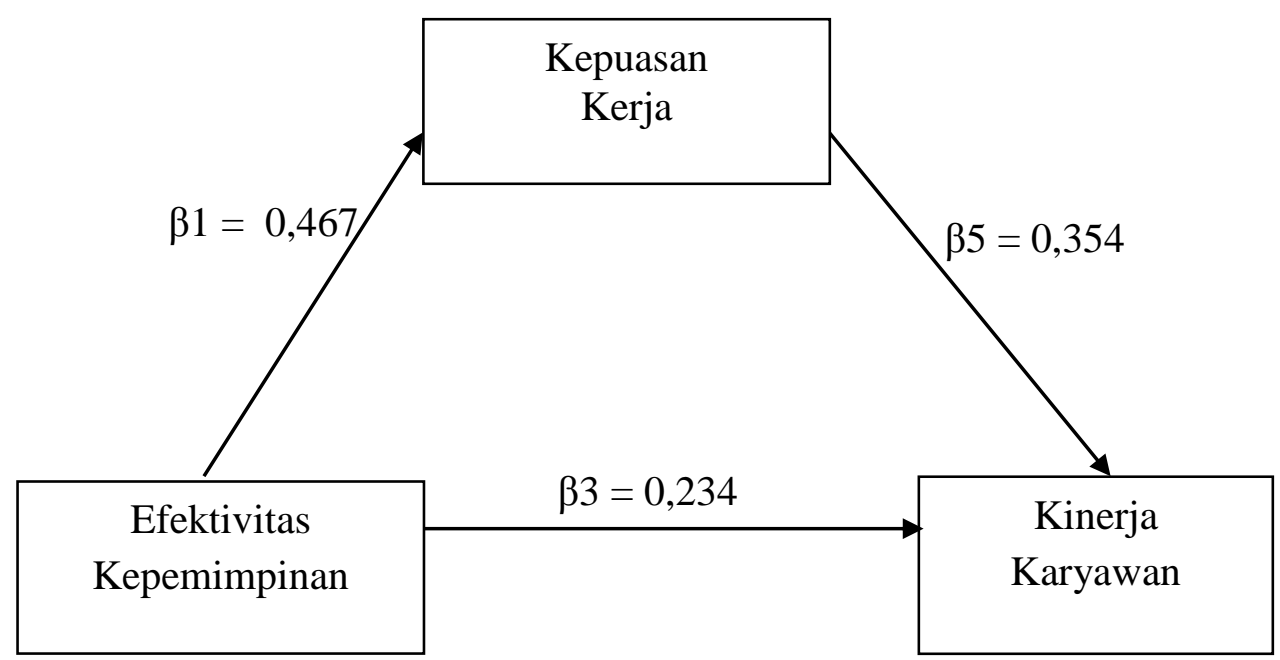

\section{Gambar 2. Pengaruh Efektivitas Kepemimpinan Terhadap Kinerja Karyawan dengan mediasi Kepuasan Kerja}

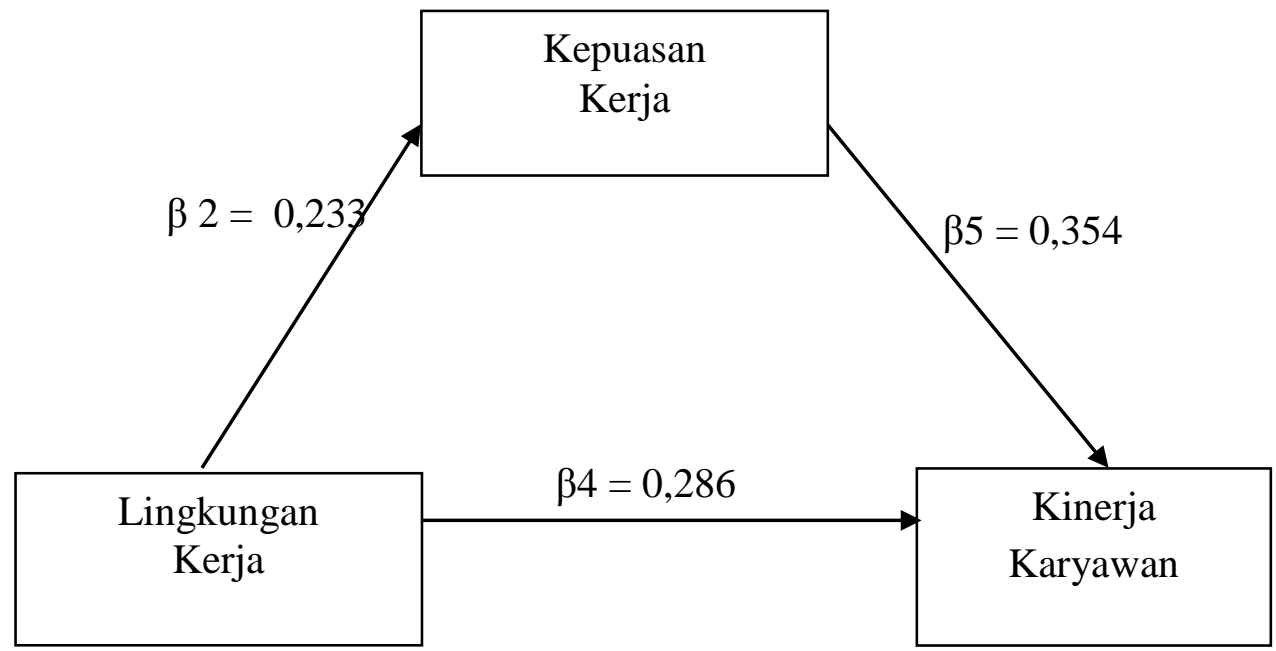

Gambar 3. Pengaruh Lingkungan Kerja terhadap Kinerja Karyawan dengan Mediasi Kepuasan kerja

\section{PENUTUP}

\section{Simpulan}

Dari hasil analisis dan pembahasan pada bab sebelumnya, maka dapat disimpulkan sebagai berikut:

1. Efektivitas kepemimpinan berpengaruh positif dan signifikan terhadap kepuasan kerja karyawan PD. BPR BKK Batang.

2. Lingkungan kerja berpengaruh positif dan signifikan terhadap kepuasan kerja karyawan PD. BPR BKK Batang.

3. Efektivitas kepemimpinan berpengaruh positif dan signifikan terhadap kinerja karyawan PD. BPR BKK Batang..
4. Lingkungan kerja berpengaruh positif dan signifikan terhadap kinerja karyawan PD. BPR BKK Batang.

5. Kepuasan kerja berpengaruh positif dan signifikan terhadap kinerja karyawan PD. BPR BKK Batang.

6. Kepuasan kerja sebagai variabel yang memediasi pengaruh efektivitas kepemimpinan terhadap kinerja karyawan PD. BPR BKK Batang.

7. Kepuasan kerja sebagai variabel yang memediasi pengaruh lingkungan terhadap kinerja karyawan PD. BPR BKK Batang. 


\section{Saran}

Adapun saran yang dapat peneliti kemukakan sebagai berikut.

1. Hendaknya pimpinan dapat lebih efektif dalam memberikan arahan kerja yang tepat kepada bawahannya agar dapat meningkatkan kinerja karyawan.

2. Hendaknya pimpinan dapat dapat menciptakan lingkungan kerja yang nyaman, agar karyawan merasakan kepuasan dalam bekerja sehingga dapat meningkatkan kinerja karyawan.

3. Bagi penelitian yang akan datang, disarankan untuk meneliti variabelvariabel lain yang mempengaruhi kinerja, seperti motivasi, kepercayaan karyawan terhadap pimpinan atau pendidikan. Serta pada objek yang berbeda yang memungkinkan mempunyai pengaruh terhadap kinerja karyawan.

\section{DAFTAR PUSTAKA}

Fanggidae, R.P.C.. (2015). Pengaruh Efektivitas Kepemimpinan Terhadap Kinerja Karyawan di Flobamora Mall Kupang. Journal Of Management (SME's). 1(1), 75-96.

Ghozali, I. (2011). Aplikasi Analisis Multivariate dengan Program SPSS. Semarang: Badan Penerbitan Universitas Diponegoro.

Heriyanti, D. (2007). Analisis Pengaruh Budaya Organisasi, Kepuasan Kerja, dan Gaya Kepemimpinan terhadap kinerja karyawan dengan Komitmen Organisasional sebagai Variabel Interverning (Studi PT. PLN (PERSERO) APJ Semarang). Tesis. Universitas Diponegoro Semarang.

Huda, R. (2012). Pengaruh Kepuasan Kerja Terhadap Kinerja Karyawan PT. Joyo Bekti Indah
Surabaya. Jurnal Universitas Wijaya Putra. Surabaya.

Jacob, V., Chattopadhyay, S.K., Sipe, T.A., Thota, A.B., Byard, G.J., Chapman, D.P., et al. (2012). Economics of collaborative care for management of Depressive disorders: a community guide systematic review. Am J Prev Med 42(5), 539-49.

Larasati, D. (2016). Pengaruh Motivasi Kerja, Insentif dan Lingkungan Kerja Terhadap Kinerja Karyawan (Studi pada Karyawan PD. BPR BKK Wonogiri). Universitas Muhammadiyah Surakarta. Surakarta.

Luthans, F. (2006). Perilaku Organisasi. Yogykarta: Penerbit Andi.

Mangkunegara, A.P. (2009). Manajemen Sumber Daya Manusia. Bandung: PT. Remaja Rosdakarya.

Masrukhin dan Waridin. (2004). Pengaruh Motivasi Kerja, Kepuasan Kerja, Budaya Organisasi

Nitisimeto, A.S. (2002). Manajemen Personalia (Manajemen Sumber Daya Manusia). Yogyakarta : Ghalia Indonesia.

Nugraha, F. A. (2009). Pengaruh Kepemimpinan, Motivasi, Pelatihan, dan Lingkungan Kerja terhadap Kinerja Karyawan pada Perusahaan Tekstil PT. Kosoema Nanda Klaten. Surakarta: Fakultas Ekonomi UMS.

Prijanto, B. dkk. (2011). Pengaruh Efektivitas Komunikasi dan Kepemimpinan Terhadap Kinerja (Studi pada Universitas Gunadharma). Jurnal Proceeding PESAT. Universitas Gunadarma. 4, 27-32. 
Riandani, D.V. (2012). Pengaruh Kepemimpinan, Motivasi, Lingkungan Kerja dan Komunikasi Terhadap Kinerja Karyawan PT. Pinnacle Apparels Semarang. Universitas Dian Nuswantoro. Semarang.

Rivai, V. (2011). Manajemen Sumber Daya Manusia Untuk Perusahaan - Dari Teori Ke Praktik. Jakart:PT. Raja Grafindo Persada.

Robbin, S. (2006). Perilaku Organisasi. Jakarta: PT. Indeks.

Rokhilah dan Darmanto, S. (2014). Pengaruh Kompetensi, Motivasi Dan Lingkungan Kerja Terhadap Kinerja Penyuluh Lapangan Program Keluarga Berencana (Plkb) Di Kabupaten Pemalang Media Ekonomi Dan Manajemen, 29(1), pp. 68-72

Septiana, H.W. (2013). Pengaruh Kepemimpinan dan Lingkungan Kerja Terhadap Kepuasan Kerja Pegawai pada Dinas Pendidikan Pemuda dan Olahraga Kota Surakarta. UNS Surakarta.

Shalahuddin, A. (2013). Pengaruh Kepemimpinan dan Lingkungan Kerja Terhadap Komitmen Organisasional Dan Kinerja Karyawan PT. Sumber Djantin di Kalimantan Barat. Jurnal Manajemen Teori dan Terapan. 6(1), 88-104.

Siagian, S.P. (2008). Manajemen Sumber Daya Manusia. PT Bumi Aksara: Jakarta.

Sugiyono. (2009). Metode Penelitian Kuantitatif Kualitatif dan $R \& D$. Bandung: Alfabeta.
Suhaji, Linawati, (2012. Pengaruh Motivasi, Kompetensi, Kepemimpinan, Dan Lingkungan Kerja Terhadap Kinerja Karyawan (Studi Pada PT. Herculon Carpet Semarang). Jurnal Kajian Akuntansi dan Bisnis.1(1).

Sujak, A. (2009). Kepemimpinan Manager (Eksistensi dalam Perilaku Organisasi). Jakarta: PT. Gramedia.

Sukanto dan Indriyo. (2000). Manajemen Personalia . Jakarta: Erlangga.

Tjandra, D. N., Setiawati, M. (2013). Analisis Pengaruh Lingkungan Kerja, Kepemimpinan, dan Motivasi Terhadap Kepuasan Kerja Karyawan Food and Beverage " $X$ " Hotel Surabaya. Jurnal Hospitality dan Manajemen Jasa. Universitas Kristen Petra. Surabaya.

Trianka. J. (2015). Pengaruh Gaya Kepemimpinan dan Lingkungan Kerja Terhadap Kepuasan Kerja PT Bank X (persero) Tbk Area Bandar Lampung. Unila. Lampung.

Triayong, E.B., dkk. (2015). Pengaruh Motivasi Kerja dan Efektivitas Kepemimpinan Camat Terhadap Kinerja Pegawai. JISIP: Jurnal Ilmu Sosial dan Ilmu Politik. Jurnal Ilmu Sosial dan Ilmu Politik. 2(2),4-14.

Umar, H. 2010. Sumber Daya Manusia. Jakarta: Gramedia Pustaka Utama.

Wicaksono, A. B. (2013). Pengaruh Efektivitas Kepemimpinan Terhadap Kepuasan Kerja Pegawai. Universitas Diponegoro. Semarang. 
MEDIA EKONOMI DAN MANAJEMEN

Vol. 32 No. 2 Juli 2017

Yanti, J.B. (2011). Pengaruh Peran Kepemimpinan, Motivasi Terhadap Kepuasan Kerja dan Kinerja Karyawan pada PT. Putra Sarana Transborneo Banjarmasin. Jurnal. Universitas Lambung Mengkurat. 